\title{
The Effect of Starch on Utilization of Casein Infused into the Abomasum of Goats
}

\author{
Tsutomu FujIHARA* and Iwao TaSAKI** \\ * Faculty of Agriculture, Kagawa University, Kagawa-ken 761-07 \\ ** Fuculty of Agriculture, Nagoya University, Nagoya-shi 464 \\ (Received December 3, 1974)
}

It was demonstrated by Chalmers et al.1) that sheep fed a low protein ration retained more nitrogen in the body and excreted less nitrogen in the urine when casein was duodenally infused than when casein was infused ruminally. Chalmers and OGILviE ${ }^{2)}$ later observed in sheep that the abomasal infusion of casein together with glucose increased nitrogen retention compared to the abomasal infusion of casein alone. The objective of the present experiment was to determine whether or not starch would influence the utilization of casein when starch and casein were simultaneously infused into the abomasum of adult goats.

\section{Experimental}

Two castrated male Japanese Saanen goats weighing about $30 \mathrm{~kg}$ were used. Each goat was fitted with a parmanent abomasal fistula by means of the method described by UKal et al. ${ }^{3)}$. The goats were kept in metabolism cages throughout the experimental period of 45 days. The first 15 days were designed as a basal feeding period, the second 15 days as a casein infusion period, and the third 15 days as a casein and starch infusion period. The goats were fed about $600 \mathrm{~g}$ of low quality hay as a daily basal diet during the three experimental periods. The quantity of casein infused was $30 \mathrm{~g}$ a day and that of starch was $60 \mathrm{~g}$. One-half the daily dose of starch and/or casein suspended in warm water of $100 \mathrm{~m} l$ was infused into the abomasum through the abomasal fistula at a rate of $150 \mathrm{~m} l$ per hour using a speed controlled injector. Feeding hay and abomasal infusion were performed twice a day at 9:00 a.m. and 5:00 p. m.. Feces and urine were collected for last 5 days in each period, and nitrogen in the feeds, feces and urine was analized by microKjeldahl method.

\section{Results and Discussion}

Apparent digestibilities of dry matter and crude protein as well as nitrogen balance are shown in Table 1. The dry matter digestibility tended to increase by the abomasal infusion of casein alone, but it increased greatly when casein and starch were infused simultaneously. Applying the valiability of dry matter digestibility for sheep ( $\pm 1.33 \%$ ) suggested by CRAMPTON and HARRIS ${ }^{4}$ to the present data, the increase of dry matter digestibility by the simultaneous infusion of casein and starch is significant. Since the casein digestibility was not increased by the simultaneous infusion of starch as discussed later, the increase of dry matter digestibility seems to be due to the better digestibility of starch infused. KaRR et al. ${ }^{5)}$ reported that the starch digestibility decreased with an increase of the quantity of starch passing into the abomasum. When $375 \mathrm{~g}$ of Jap. J.Zootech.Sci., 46, (6): 377-379. 
Table 1. Apparent digestibility and nitrogen balance

\begin{tabular}{|c|c|c|c|c|c|c|}
\hline \multicolumn{2}{|l|}{ Goat } & \multicolumn{2}{|l|}{ A } & \multicolumn{3}{|c|}{$\mathbf{B}$} \\
\hline \multicolumn{7}{|l|}{ Feed intake (g/day) } \\
\hline Hay, oral & 600 & 600 & 600 & 600 & 610 & 600 \\
\hline Casein, abomasal & - & 30 & 30 & - & 30 & 30 \\
\hline Starch, abomasal & 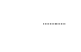 & - & 60 & - & - & 60 \\
\hline \multicolumn{7}{|l|}{ Digestibility (\%) } \\
\hline Dry matter & 38.8 & 40.6 & 52.1 & 40.7 & 45.6 & 69.0 \\
\hline Crude protein & 53.0 & 60.3 & 59.0 & 58.0 & 66.0 & 65.0 \\
\hline Casein & - & 71.5 & 68.2 & - & 78.5 & 75.8 \\
\hline \multicolumn{7}{|l|}{ Nitrogen balance (g/day) } \\
\hline \multirow{2}{*}{$\begin{array}{r}\text { Intake, total } \\
\text { oral }\end{array}$} & 6.3 & 10.4 & 10.4 & 6.3 & 10.5 & 10.4 \\
\hline & 6.3 & 6.3 & 6.3 & 6.3 & 6.4 & 6.3 \\
\hline abomasal & - & 4.1 & 4.1 & - & 4.1 & 4.1 \\
\hline \multirow{2}{*}{$\begin{array}{r}\text { Excretion, total } \\
\text { fecal }\end{array}$} & 5.2 & 7.5 & 6.9 & 5.1 & 7.1 & 6.5 \\
\hline & 3.2 & 4.2 & 4.5 & 2.9 & 3.5 & 3.6 \\
\hline Urinary & 2.0 & 3.3 & 2.4 & 2.2 & 3.6 & 2.9 \\
\hline \multirow{3}{*}{$\begin{array}{l}\text { Retention, total } \\
\text { from casein* }\end{array}$} & 1.1 & 2.9 & 3.5 & 1.2 & 3.4 & 3.9 \\
\hline & - & 1.8 & 2.4 & - & 2.2 & 2.7 \\
\hline & - & $(61)$ & $(86)$ & & (68) & (87) \\
\hline
\end{tabular}

* Calculated values based on the basal hay feeding.

Values in parenses show the efficiency of casein nitrogen retention as indicated in precent of digested casein nitrogen

starch ( $6 \%$ of the daily ration) was recovered from the abomasum the starch digestibility was very high, being $92.7 \%$. While, its digestibility decreased to $64.3 \%$ when $982 \mathrm{~g}$ of $\operatorname{starch}(22 \%$ of a daily ration) was recovered from the abomasum. According to the authors' previous report ${ }^{6}$, when $60 \mathrm{~g}$ of casein and $360 \mathrm{~g}$ of starch together with necessary amounts of minerals and vitamins were infused daily into the abomasum of goats, the apparent digestibility of starch was rather low, being $61-65 \%$, whereas it was $97-98 \%$ when the same diet was introduced ruminally. Then the authors concluded that starch is not easily digested in the post-ruminal alimentary tract when infused directly into the abomasum of ruminants. However, the quantity of starch infused into the abomasum was so small in the present experiment, being about $9 \%$ of the daily ration, that as demonstrated by KARR et al.5) the starch digestion seems to be much higher than the authors' previous data ${ }^{6}$.

Fecal nitrogen output tended to increase by the casein infusion irrespective of the simultaneous infusion of starch. The digestibility of crude protein also tended to increase by the casein infusion. Based on the crude protein digestibility of the basal diet, the digestibility of abomasally infused casein was calculated. The result shows that the casein digestibility was not affected by the simultaneous infusion of starch with casein, and this is in accordance with that of LiTTLE and MitcheLL ${ }^{7)}$ using sheep infused $50 \mathrm{~g}$ of casein, and also that of FuJIHARA and TASAKI ${ }^{6)}$ using goats infused $60 \mathrm{~g}$ of casein.

Urinary nitrogen excretion was increased by the casein infusion, but this increase was lessened by the simultaneous infusion of starch. Consequently, nitrogen retention due to the abo- 


\section{Utilization of Casein in Goats}

masally infused casein was increased by the starch infusion. This result is in agreement with that of Chalmers and Ocilviz ${ }^{2)}$ using sheep infused casein together with glucose into the abomasum. It is suggested from these results that the utilizability of casein infused into the abomasum of ruminants was improved by the simultaneous infusion of not only glucose but also starch.

LitTle and Mitchellil reported that wethers retained 19\% of digested casein nitrogen in the body when $50 \mathrm{~g}$ of casein was infused into the abomasum. In the present experiment, however, 61-68\% of digested casein nitrogen retained in adult goats when only casein was into the abomasum. Moreover, when casein and starch were simultaneously infused, the efficiency of nitrogen retention increased to $86-87 \%$. TASAKI et al. ${ }^{8)}$ also observed that the abomasal infusion of casein ( $30 \mathrm{~g} /$ day) increased nitrogen retention when compared to the oral feeding of casein. FUJIHARA and TASAKI $^{9}$ demonstrated tha ammonia is rarely produced in the rumen when no protein is introduced into the rumen. The increase of nitrogen retention in the abomasal infusion of casein can be explained by the fact demonstrated by FUJHARA and TASAKI, because no nitrogen loss due to ammonia production is expected when casein was introduced into the abomasum. Directly introduced casein into the abomasum may be hydrolyzed and absorbed in the intestine.

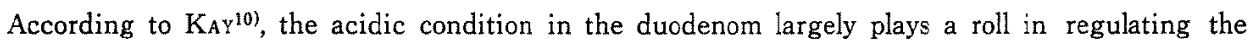
secretion of proteolytic enzymes. This is a possible reason why the simultaneous infusion of starch with casein increases the nitrogen retention when compared the infusion of casein alone, because intestinal $\mathrm{pH}$ may be reduced by the starch infusion into the abomasum.

\section{References}

1) Chalmers, M. I., D. P. Cuthbertson, and R. L. M. Synge, J Agr Sci 44: 254-263. 1954.

2) Chalmers, M. I., and J.M. Ogilvie, Proc Nutr Soc 19: xix. 1960.

3) Ukai, A., T. Fujihara, F. Shibata, and I. Tasaki, Jap J Zootech Sci 44: 625-627. 1973.

4) Crampton, E.W., and L. E. Harris, Applied Animal Nutrition 116. Freeman Co. San Francisco. 1969.

5) Karr, M.R., C. O. Little, and G. E. Mitchell, Jr., J Anim Sci 25: 652-645. 1966.

6) Fujihara, T., and I. Tasaki, Jap J Zootech Sci 44: 125-127, 1973.

7) Little, C. O., and G.E., Mitchell, Jr., J Anim Sci 26: 411-413. 1967.

8) Tasaki, I., F. Shibata, and T. Ito, Jap J Zootech Sci 41: 88-96. 1970.

9) Fujihara, T., and I. TAsaki, Jap J Zootech Sci 44: 572-575. 1973.

10) KaY, R. N., Proc Nutr Soc 28: 140-151. 1969. 